\title{
镧掺杂的二氧化锰/碳纳米管电化学超级电容器复合电极
}

\author{
薛荣阎景旺*田颖衣宝廉 \\ (中国科学院大连化学物理研究所, 辽宁大连 116023)
}

\begin{abstract}
摘要：尽管在二氧化锰/多壁碳纳米管 $\left(\mathrm{MnO}_{2} / \mathrm{MWCNTS}\right)$ 上获得了较高的比电容, 低电导率仍是制约 $\mathrm{MnO}_{2}$ 担 载量或膜厚度提高的主要障碍. 另一个问题是 $\mathrm{MnO}_{2} / \mathrm{MWCNTS}$ 的循环稳定性远低于活性炭. 所以截止到目前 这一新型材料的应用仍然受到很大的限制. 本文采用原位还原的方法制备锞掺杂二氧化锰/多壁碳纳米管电 化学超级电容器复合电极材料. 分别通过透射电镜(TEM)、扫描电镜(SEM)、X射线衍射(XRD)和傅里叶变换红 外(FTIR)光谱等技术对这些复合材料的形貌与结构进行了分析. 采用循环伏安法、恒电流充放电法和交流阻 抗法对其进行了电化学性能的研究. 研究结果表明, 通过还原 $\mathrm{MnO}_{4}$ 可以在 MWCNTs 上形成 La 掺杂 $\mathrm{MnO}_{2}$ 复 合材料. $\mathrm{La}$ 掺杂降低了复合电极的电阻, 这是因为 $\mathrm{La}$ 的引入可以增大 $\mathrm{MnO}_{2}$ 的晶格缺陷, 从而提高材料的电 导率以及电极的电化学性能. 因此 $\mathrm{La}$ 掺杂是克服 $\mathrm{MnO}_{2}$ 本征导电性差的有效途径之一. 掺杂 $\mathrm{La}$ 可以在不增大 电极电阻的情况下提高 $\mathrm{MnO}_{2}$ 的担载量或膜厚度. La掺杂的更重要的作用是使以 $\mathrm{MnO}_{2} / \mathrm{MWCNTS}$ 作电极的对 称电化学超级电容器的循环性能得到显著改善. 此外, La掺杂也使复合电极的比电容得到一定程度的提高.
\end{abstract}

关键词：超级电容器; 多壁碳纳米管; 针并; 二氧化锰; 赝电容 中图分类号: 0646

\section{Lanthanum Doped Manganese Dioxide/Carbon Nanotube Composite Electrodes for Electrochemical Supercapacitors}

\author{
XUE Rong YAN Jing-Wang* TIAN Ying YI Bao-Lian \\ (Dalian Institute of Chemical Physics, Chinese Academy of Sciences, Dalian 116023, Liaoning Province, P. R. China)
}

\begin{abstract}
Although higher specific capacitances have been achieved for manganese dioxide/multi-walled carbon nanotubes $\left(\mathrm{MnO}_{2} / \mathrm{MWCNTs}\right)$, the low conductivity of $\mathrm{MnO}_{2}$ is still the main obstacle in increasing its loading or film thickness. Another problem is that the cycling stability of $\mathrm{MnO}_{2} / \mathrm{MWCNTs}$ is much lower than that of activated carbon electrodes. Therefore, this new type of electrode material is still limited in application until now. In this paper, lanthanum doped $\mathrm{MnO}_{2} / \mathrm{MWCNTs}$ composites were prepared by an in situ redox method. The surface morphology and phase structure of the as-prepared samples were investigated by transmission electron microscopy (TEM), scanning electron microscopy (SEM), X-ray diffraction (XRD), and Fourier transform infrared (FTIR) spectrometry. The electrochemical properties were investigated by cyclic voltammetry (CV), galvanostatic charge/discharge, and electrochemical impedance spectroscopy (EIS). The La-doped $\mathrm{MnO}_{2}$ could be formed on the MWCNTs by the reduction of $\mathrm{MnO}_{4}^{-}$. The resistance of the composite electrodes decreased because La doping increases the number of imperfections in the $\mathrm{MnO}_{2}$ lattice, which improves the electrical conductivity and the electrochemical activity of the electrode. La doping is, therefore, an effective way to overcome the intrinsic low electric conductivity of $\mathrm{MnO}_{2}$, which facilitates an increase in the loading or the film thickness of $\mathrm{MnO}_{2}$ without increasing electrode resistance. The major effect of La doping is a significant improvement in the charge/discharge
\end{abstract}

Received: February 24, 2011; Revised: July 13, 2011; Published on Web: August 15, 2011.

"Corresponding author. Email: yanjw@dicp.ac.cn; Tel: +86-411-84379685.

The project was supported by the Important Directional Project of 'the Research and Exploration of Supercapacitor Storage System for Electric

Vehicle’ from Dalian Institute of Chemical Physics, Chinese Academy of Sciences, China.

中国科学院大连化学物理研究所重要方向性项目 “电动汽车用超级电容器储能系统的研究与开发”资助

(C) Editorial office of Acta Physico-Chimica Sinica 
cycling performance of a symmetric electrochemical supercapacitor with electrodes composed of $\mathrm{MnO}_{2} /$ MWCNTs. The specific capacitance of the composite electrodes was improved by La doping.

Key Words: Supercapacitor; Multi-walled carbon nanotube; Lanthanum; Manganese dioxide; Pseudocapacitance

\section{Introduction}

Electrochemical supercapacitors (ECs) are becoming attractive electrical storage devices in computers, power electronics, and electric vehicles for providing transiently high power. ${ }^{1-3}$ ECs can be classified into two categories, depending on the energy storage mechanism. One is electrical double layer capacitors (EDLCs), in which activated carbons with high surface area are used as electrode material. ${ }^{1-4}$ The other category is pseudocapacitors, in which fast and reversible Faraday reactions are utilized for charge storage. Metal oxides and conducting polymers are examples of pseudo-capacitive active materials. ${ }^{1}$

An active electrode material with high capacitive performance is indispensable to develop an advanced supercapacitor device. Recently, metal oxide-carbon nanotubes (CNTs) composites, such as $\mathrm{RuO}_{2} / \mathrm{CNTs}, \mathrm{NiO} / \mathrm{CNTs}, \mathrm{MnO}_{2} / \mathrm{CNTs}$, have been attracting interest by taking advantage of the excellent electrical conductivity and chemical stability of CNTs and the high capacitance of metal oxides., ${ }^{5,6}$ Among them, $\mathrm{MnO}_{2} / \mathrm{CNTs}$ composite has attracted much attention from both the academic and industrial fields due to its high specific capacitance, environmentally friendliness, and cost effectiveness.

Although higher specific capacitances have been achieved on $\mathrm{MnO}_{2} / \mathrm{CNTs}$, the low conductivity of $\mathrm{MnO}_{2}$ is still the main obstacle for increasing the loading of $\mathrm{MnO}_{2}$ or the thickness of $\mathrm{MnO}_{2}$ films. ${ }^{8}$ Another problem is that the cycling stability of $\mathrm{MnO}_{2} / \mathrm{CNTS}$ is much lower than that of the activated carbon electrodes, ${ }^{9}$ so that this new type of electrode materials is still limited in applications until now.

Recently, it has been reported that lanthanum has obvious influence on the capabilities of many materials. ${ }^{10,11}$ However, little attention has been paid on the composites of La-doped $\mathrm{MnO}_{2} / \mathrm{CNTs}$.

In this work we have synthesized and employed La-doped $\mathrm{MnO}_{2} / \mathrm{MWCNTs}$ composites as electrodes for electrochemical capacitors, and electrochemical performances have been investigated. It was demonstrated that La doping led to significant improvements in specific capacitance and cycling stability in a symmetric two-electrode capacitor. Moreover, doping $\mathrm{MnO}_{2}$ with $\mathrm{La}$ is an effective method to overcome the intrinsic low conductivity of $\mathrm{MnO}_{2}$, which facilitates the increase of the loading or thickness of $\mathrm{MnO}_{2}$ films without raising the electrode resistance.

\section{Experimental}

Commercial multi-walled carbon nanotubes (MWCNTs) (Chengdu Institute of Organic Chemistry) were used to prepare
$\mathrm{MnO}_{2} / \mathrm{MWCNTs}$ and $\mathrm{La}-\mathrm{MnO}_{2} / \mathrm{MWCNTs}$ composites. The MWCNTs were refluxed in a mixture of concentrated sulfuric acid and nitric acid $(3: 1, V / V)$ for $30 \mathrm{~min}$, and then washed to neutral using deionized water and dried in an electric oven.

The $\mathrm{MnO}_{2} / \mathrm{MWCNTs}$ composites were directly synthesized by a redox reaction between the $\mathrm{MnO}_{4}^{-}$and pretreated MWCNTs. ${ }^{12}$ Firstly, 0.94 g KMnO$_{4}(99.5 \%)$ was dissolved into distilled water to form $0.1 \mathrm{~mol} \cdot \mathrm{L}^{-1}$ solution and heated to $70{ }^{\circ} \mathrm{C}$. Then $0.3 \mathrm{~g}$ pretreated MWCNTs was added into the $\mathrm{KMnO}_{4}$ solution. The mixture was stirred at $70{ }^{\circ} \mathrm{C}$ until the purple color faded away. The $\mathrm{MnO}_{2} / \mathrm{MWCNTs}$ composite suspension was filtered, washed, and dried at $100{ }^{\circ} \mathrm{C}$ for $24 \mathrm{~h}$ in a vacuum oven.

MWCNTs supported $\mathrm{La}-\mathrm{MnO}_{2}\left(\mathrm{La}-\mathrm{MnO}_{2} / \mathrm{MWCNTs}\right)$ composites were prepared by a similar method with adding $\mathrm{La}\left(\mathrm{NO}_{3}\right)_{3} \cdot 6 \mathrm{H}_{2} \mathrm{O}(98.0 \%)$ and pretreated MWCNTs into the $\mathrm{KMnO}_{4}$ solution. Several samples with different La:Mn atomic ratios $(0.2: 9.8,0.5: 9.5,1: 9,1.5: 8.5,2: 8)$ were prepared, and were marked as $\mathrm{La}-\mathrm{MnO}_{2}(0.2: 9.8) / \mathrm{MWCNTs}, \mathrm{La}-\mathrm{MnO}_{2}(0.5$ : 9.5)/MWCNTs, La-MnO $(1: 9) / \mathrm{MWCNTs}, \mathrm{La}-\mathrm{MnO}_{2}(1.5: 8.5) /$ MWCNTs, and La-MnO 2 (2:8)/MWCNTs, respectively.

The crystallographic structures of the materials were determined by powder X-ray diffraction (XRD) on a diffractometer (D/MAX-IIIC, Rigaku) using $\mathrm{Cu} K_{a}$ radiation $(\lambda=0.15406 \mathrm{~nm})$. The morphology of the composites was examined using a transmission electron microscope (TEM, Philips F-20 TECNAI G ${ }^{2}$, $200 \mathrm{kV}$ ). Surface morphological images of the carbon nanotubes were taken by a scanning electron microscope (S-800, Hitachi High-Technologies Co., Japan). Infrared (IR) spectroscopic analysis was carried out using an AVATAR 360 Fourier transform infrared (FT-IR) spectrometer ( $\mathrm{KBr}$ pellet, wave- number range, $1000-4000 \mathrm{~cm}^{-1}$ ).

The electrical conductivity of the composites was measured by ac impedance method on PARSTAT 2273 controlled by a computer. Disk samples were prepared by pressing the powder in a die under $20 \mathrm{MPa}$ to ensure that dense samples were formed.

The active materials, carbon black, and $6 \%$ of polytetrafluoroethylene (PTFE) emulsion were uniformly mixed by a mortar and pestle with a ratio of 80:15:5. The mixtures were then rolled to form uniform membranes, and dried at $60{ }^{\circ} \mathrm{C}$. The membranes were cut into circular pieces $\left(\sim 0.5 \mathrm{~cm}^{2}\right)$ and pressed onto nickel foam to form working electrodes.

The electrochemical properties of the $\mathrm{MnO}_{2} / \mathrm{MWCNTs}$ and $\mathrm{La}-\mathrm{MnO}_{2} / \mathrm{MWCNTs}$ composites were characterized by cyclic voltammetry $(\mathrm{CV})$ and electrochemical impedance spectrosco- 
py (EIS) in three-electrode cells using a PARSTAT 2273 electrochemical station (Princeton applied research Co., Ltd., USA). A Hg/ $\mathrm{Hg}_{2} \mathrm{SO}_{4}$ (saturated $\mathrm{K}_{2} \mathrm{SO}_{4}, 0.6151 \mathrm{~V}$ versus normal hydrogen electrode (NHE)) standard electrode was used as reference electrode. Ni foam was used as counter electrode. The measurements were carried out in $0.1 \mathrm{~mol} \cdot \mathrm{L}^{-1} \mathrm{Na}_{2} \mathrm{SO}_{4}(99.0 \%)$ aqueous electrolyte with $\mathrm{pH} 5.4$ at room temperature. Charge/ discharge cycle tests were performed using a battery testing system (BTS50V50mA, Neware Electronic Co. Ltd.) at different constant current densities. Galvanostatic charge/discharge cycling performances at a constant current of $100 \mathrm{~mA} \cdot \mathrm{g}^{-1}$ were investigated for two- and three-electrode systems, respectively.

\section{Results and discussion}

\subsection{Structural characterization}

Fig.1(a, b, c) shows the TEM images of the acid-treated MWCNTs, $\mathrm{MnO}_{2} / \mathrm{MWCNTs,}$ and La-MnO $2(1: 9) / \mathrm{MWCNTs}$ composites. It is observed that the diameter of the acid-treated
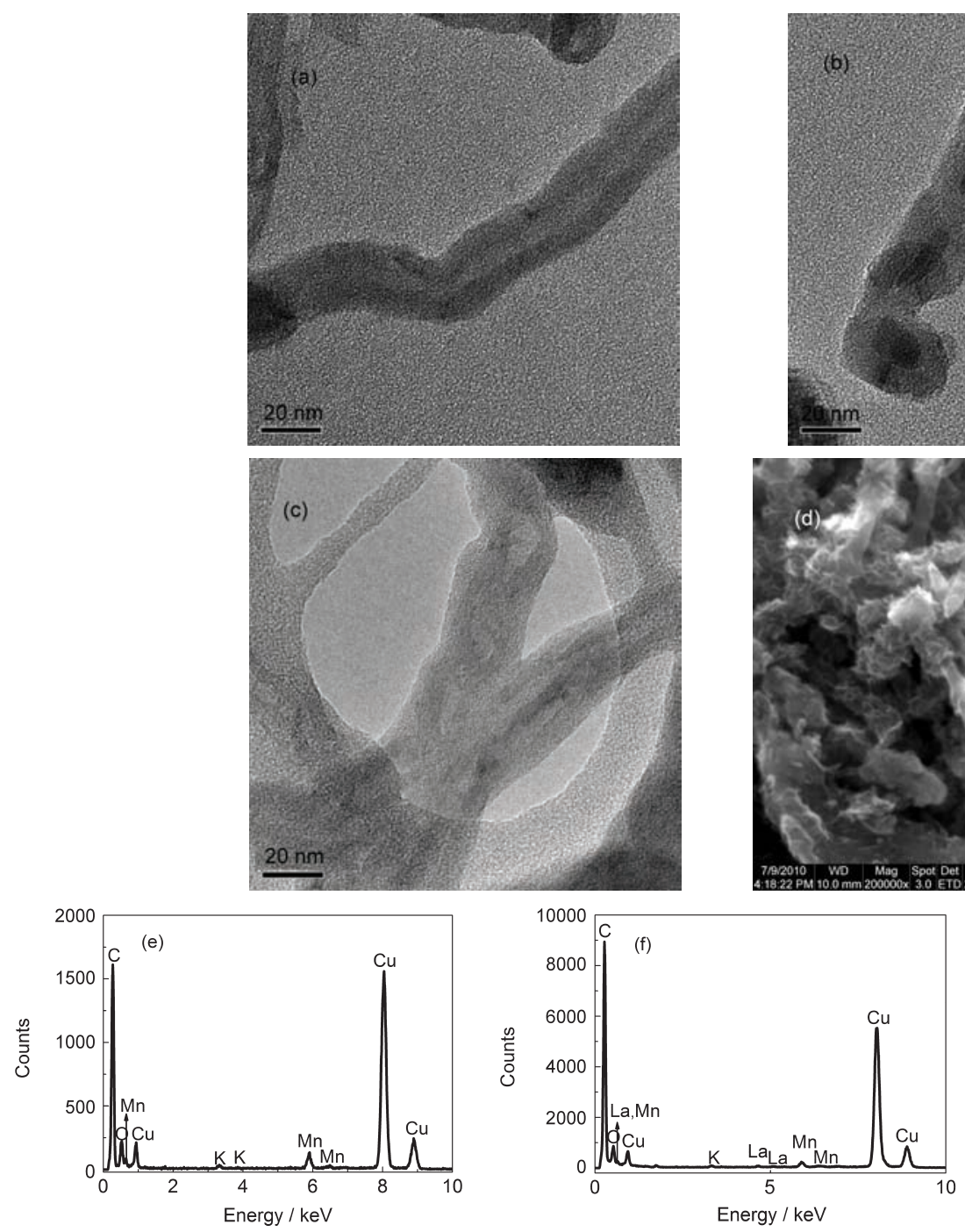

Fig.1 TEM images of (a) acid-treated MWCNTs, (b) $\mathrm{MnO}_{2} / \mathrm{MWCNTs}_{\text {, (c) La-MnO}}(1: 9) / \mathrm{MWCNTs}$ (d) SEM image of La-MnO (1:9)/ MWCNTs; EDX spectra of (e) $\mathrm{MnO}_{2} / \mathrm{MWCNT}$ and (f) $\mathrm{La}_{\mathrm{MnO}}(1: 9) / \mathrm{MWCNTs}$ from TEM; (g) EDX spectrum of La-MnO$(1: 9) /$

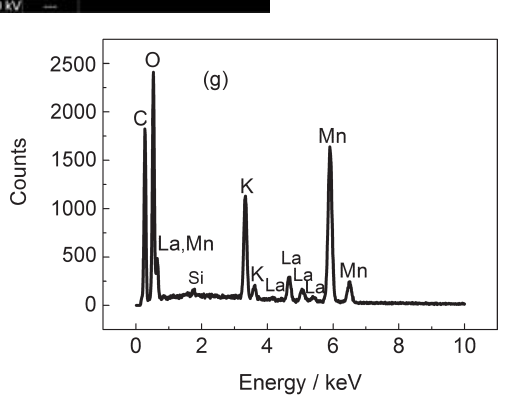

MWCNTs is around $20 \mathrm{~nm}$ and the wall of MWCNTs is smooth. The synthesized products of $\mathrm{MnO}_{2} / \mathrm{MWCNTs}$ and La$\mathrm{MnO}_{2}$ (1:9)/MWCNTs were composed of fibrils of $30 \mathrm{~nm}$ in diameter, slightly bigger than the acid-treated MWCNTs. Fig.1 (d) gives the SEM image of $\mathrm{La}-\mathrm{MnO}_{2}(1: 9) / \mathrm{MWCNTs}$. Energy dispersive X-ray spectra (EDX) in Fig.1(f, g) confirmed the existence of $\mathrm{La}$ in the composites. In addition, the $\mathrm{K}$ peak in Fig. 1 (e, $f, g$ ) is attributed to the charging mechanism of $\mathrm{MnO}_{2}$ with $\mathrm{K}^{+}$by the following reaction: ${ }^{13}$

$$
\mathrm{MnO}_{2}+\mathrm{K}^{+}+\mathrm{e}^{-} \rightleftharpoons \mathrm{KMnO}_{2}
$$

In a $\mathrm{pH}$ neutral solution, the reaction between MWCNTs and $\mathrm{MnO}_{4}^{-}$is: ${ }^{14}$

$$
4 \mathrm{MnO}_{4}^{-}+3 \mathrm{C}+\mathrm{H}_{2} \mathrm{O} \rightleftharpoons 4 \mathrm{MnO}_{2}+\mathrm{CO}_{3}^{2-}+2 \mathrm{HCO}_{3}^{-}
$$

Thus, $\mathrm{MnO}_{4}^{-}$was reduced by MWCNTs.

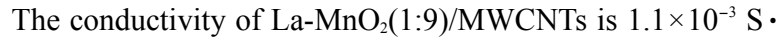
$\mathrm{cm}^{-1}$. It is higher than that of the $\mathrm{MnO}_{2} /$ MWCNTs composite $\left(4.9 \times 10^{-4} \mathrm{~S} \cdot \mathrm{cm}^{-1}\right)$. The enhancement to the electrical conductivity of the composites is due to the introduction of lanthanum
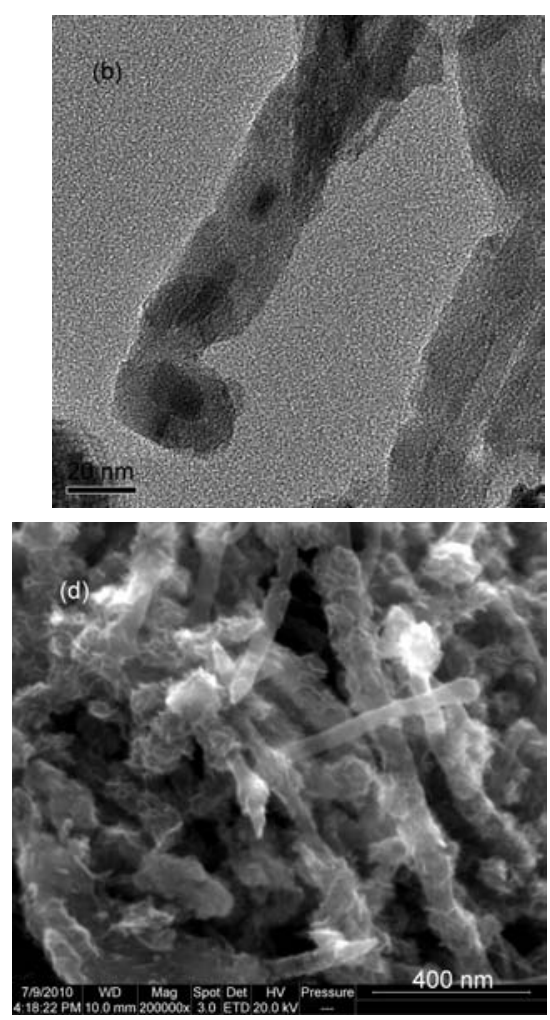
into the composites.

Fig. 2 shows the XRD patterns of the $\mathrm{MnO}_{2} / \mathrm{MWCNTs}$ and La- $\mathrm{MnO}_{2}(1: 9) / \mathrm{MWCNTs}$ composites. As shown in Fig.2, except three peaks corresponding to the structure of pristine MWCNTs, there are two broad peaks at $2 \theta$ around $37^{\circ}$ and $66^{\circ}$. These two peaks can be indexed to birnessite-type $\mathrm{MnO}_{2}$ (Joint Committee on Powder Diffraction Standards (JCPDS) card No.42-1317). ${ }^{12}$ Therefore, the composite should be considered as MWCNTs coated by birnessite-type $\mathrm{MnO}_{2}$. In addition, the characteristic peaks of La-doped $\mathrm{MnO}_{2} / \mathrm{MWCNTs}$ are weaker and broader than those of $\mathrm{MnO}_{2} / \mathrm{MWCNTs}$. The diffraction peaks of La-doped $\mathrm{MnO}_{2} / \mathrm{MWCNTs}$ are not apparently shifted in comparison with $\mathrm{MnO}_{2} / \mathrm{MWCNTs}$ and no diffraction peaks of compounds containing La can be observed. So it is reasonable to suppose that $\mathrm{La}$ is dispersed into the lattice of $\mathrm{MnO}_{2}$. The ionic radius of $\mathrm{La}^{3+}(0.106 \mathrm{~nm})$ is much greater than that of $\mathrm{Mn}^{4+}(0.052 \mathrm{~nm})$, which may increase the imperfection of the crystalline structure of $\mathrm{MnO}_{2}$, further enhancing the electrochemical activity of the electrode.

Moreover, the acid treatment may modify the MWCNTs surface with carbonyl and carboxyl hydroxyl groups. As can be seen in the FTIR spectrum of functionalized MWCNTs in the range of 1000-4000 $\mathrm{cm}^{-1}$ (Fig.3), a broad absorption band at $3430 \mathrm{~cm}^{-1}$ is attributed to the hydroxyl group. ${ }^{15}$ This band might be assigned to the stretching vibration of $\mathrm{OH}$ groups ${ }^{16}$ and also the $-\mathrm{OH}$ functional groups due to the chemical treatment during the functionalization process. ${ }^{17} \mathrm{~A}$ small peak at $1684 \mathrm{~cm}^{-1}$ is associated with the $\mathrm{C}=\mathrm{O}$ stretching of the carboxylic acid $(-\mathrm{COOH})$ group. ${ }^{18}$ The peak at $1642 \mathrm{~cm}^{-1}$ is due to $\mathrm{C}=\mathrm{C}$ stretching of the $\mathrm{CNT}^{19}$ The peak at $1403 \mathrm{~cm}^{-1}$ is due to $\mathrm{O}-\mathrm{H}$ bending deformation in $-\mathrm{COOH}$. The peak at 1170 $\mathrm{cm}^{-1}$ can be inferred as $\mathrm{C}-\mathrm{O}$ bond stretching. ${ }^{18}$ Thus, the generation of $-\mathrm{OH}$ and $-\mathrm{COOH}$ groups on CNTs due to functionalization is observed. These groups are more vulnerable to oxidation, ${ }^{14}$ and may initiate the reaction among carbon, $\mathrm{KMnO}_{4}$, and $\mathrm{La}\left(\mathrm{NO}_{3}\right)_{3}$.

\subsection{Electrochemical characterization}

Fig. 4 shows cyclic voltammograms in a three-electrode cell system using the acid-treated MWCNTs, $\mathrm{MnO}_{2} / \mathrm{MWCNTs}$, and La- $\mathrm{MnO}_{2}(1: 9) / \mathrm{MWCNTs}$. All the acid-treated MWCNTs and

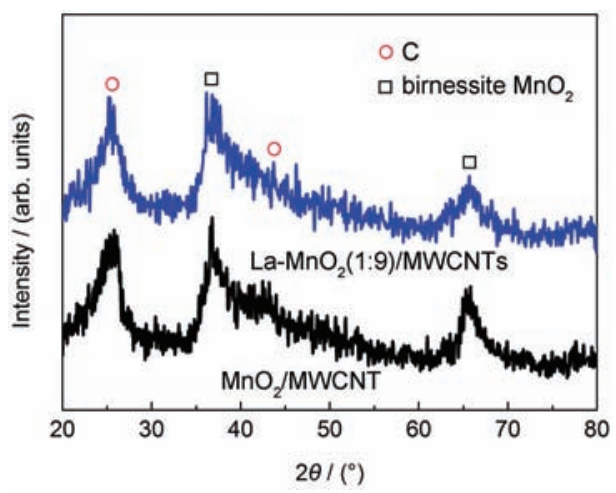

Fig.2 XRD patterns of the as-prepared $\mathrm{MnO}_{2} / \mathrm{MWCNT}$ and $\mathrm{La}_{\mathrm{MnO}}(1: 9) / \mathrm{MWCNTs}$

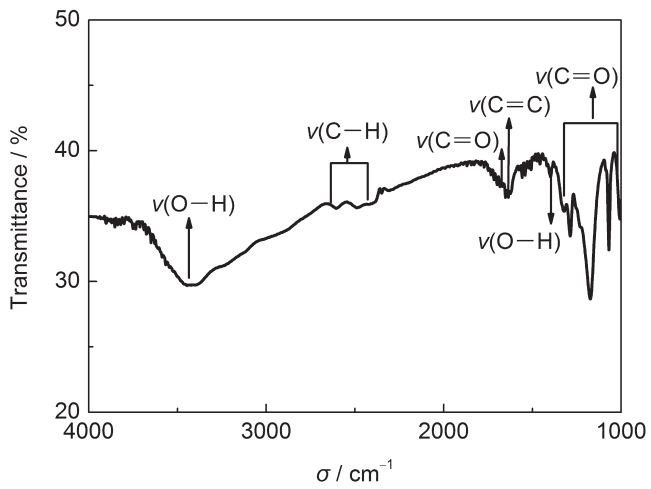

Fig.3 FTIR spectrum of functionalized MWCNTs

the composites of $\mathrm{MnO}_{2} / \mathrm{MWCNTs}$ and $\mathrm{La}-\mathrm{MnO}_{2}(1: 9) / \mathrm{MW}-$ CNTs exhibited square-shaped CV curves that indicated an ideal capacitive behavior. ${ }^{1}$ Higher current densities in the $\mathrm{CV}$ curves suggest higher specific capacitances. From the CVs, specific capacitance values are calculated using the following formula:

$$
C=\frac{1}{v\left(V_{\mathrm{c}}-V_{\mathrm{a}}\right)} \int_{V_{\mathrm{a}}}^{V_{\mathrm{c}}} I(V) \mathrm{d} V
$$

where $C$ refers to the specific capacitance $\left(\mathrm{F} \cdot \mathrm{g}^{-1}\right), v$ is the potential scan rate $\left(\mathrm{mV} \cdot \mathrm{s}^{-1}\right), V_{\mathrm{c}}-V_{\mathrm{a}}$ is the sweep potential range during discharging, and $I(V)$ refers to the response current density $\left(\mathrm{A} \cdot \mathrm{g}^{-1}\right){ }^{20}$ The specific capacitances for MWCNTs, $\mathrm{MnO}_{2} /$ MWCNTs, and $\mathrm{La}^{-\mathrm{MnO}_{2}}$ (1:9)/MWCNTs electrodes were 34, 117 , and $130 \mathrm{~F} \cdot \mathrm{g}^{-1}$ at a scan rate of $2 \mathrm{mV} \cdot \mathrm{s}^{-1}$. The composites of $\mathrm{MnO}_{2} / \mathrm{MWCNTs}$ and $\mathrm{La}-\mathrm{MnO}_{2}(1: 9) / \mathrm{MWCNTs}$ showed much higher capacitance than the acid-treated MWCNTs. When compared with the composite of $\mathrm{MnO}_{2} / \mathrm{MWCNTs}$, La$\mathrm{MnO}_{2}(1: 9) / \mathrm{MWCNTs}$ showed a higher specific capacitance, which can be attributed to the combination of pseudocapacitance from $\mathrm{La}-\mathrm{MnO}_{2}$ and electrical double layer (EDL) capacitance from MWCNTs.

$\mathrm{CVs}$ in a three-electrode cell system recorded for the composite electrodes with various La:Mn atomic ratios are presented in Fig.5A. Although all the composites with different La: $\mathrm{Mn}$ atomic ratios exhibited nearly square-shaped $\mathrm{CV}$ curves that indicated an ideal capacitive behavior, ${ }^{1}$ the composites

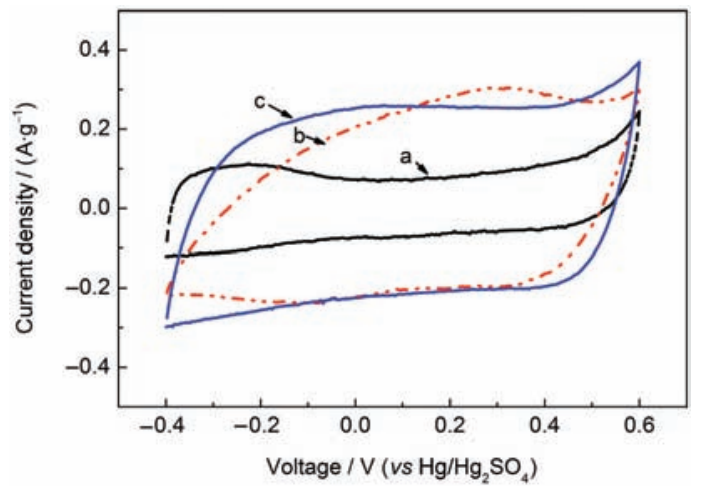

Fig.4 Cyclic voltammograms in a three-electrode cell system using (a) acid-treated MWCNTs, (b) $\mathrm{MnO}_{2} / \mathrm{MWCNTs}$, and (c) La-MnO $(1: 9) / M W C N T s$ measured in $0.1 \mathrm{~mol} \cdot \mathrm{L}^{-1} \mathrm{Na}_{2} \mathrm{SO}_{4}$ at a scan rate of $2 \mathrm{mV} \cdot \mathrm{s}^{-1}$ 

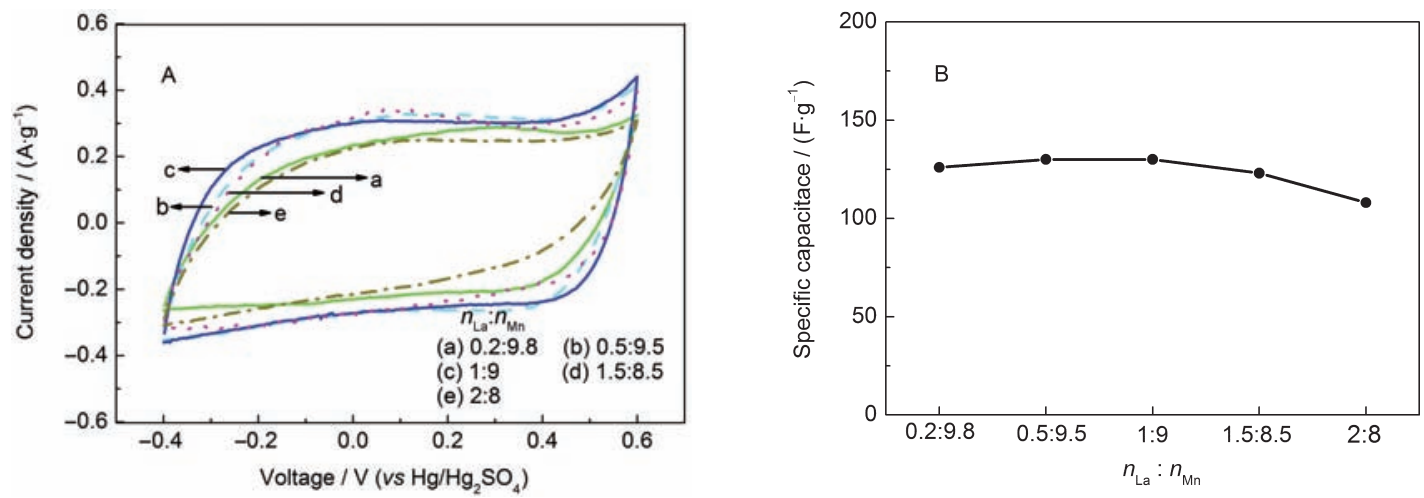

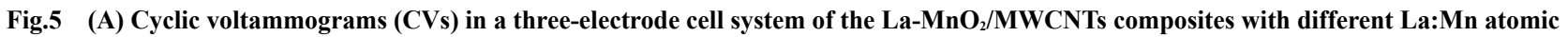
ratios measured in $0.1 \mathrm{~mol} \cdot \mathrm{L}^{-1} \mathrm{Na}_{2} \mathrm{SO}_{4}$ at a scan rate of $2 \mathrm{mV} \cdot \mathrm{s}^{-1}$; (B) the specific capacitance obtained from $\mathrm{CVs}$ with different La:Mn atomic ratios

with La:Mn atomic ratio of 1:9 exhibited a more squared geometry with a higher enclosed area than others. The variation in the specific capacitances obtained from CVs as a function of La:Mn atomic ratios is plotted in Fig.5B. The specific capacitance was firstly ascending and then descending with the La: $\mathrm{Mn}$ atomic ratio. The highest specific capacitance of $130 \mathrm{~F} \cdot \mathrm{g}^{-1}$ can be obtained for the composites with the La:Mn atomic ratios of 0.5:9.5 and 1:9. An apparent characteristic of CVs is that the composite with the La:Mn atomic ratio of 1:9 exhibited a nearly rectangular $I-V$ curve with a steep increment in current within the potential range between -0.4 and $-0.3 \mathrm{~V}$, which represents an ideal behavior of supercapacitor. ${ }^{21}$ Therefore, the optimized La:Mn atomic ratio in the $\mathrm{La}-\mathrm{MnO}_{2} / \mathrm{MWCNTs}$ composite is $1: 9$.

Fig.6a shows the galvanostatic charge-discharge behavior of two electrode cells built with the acid-treated MWCNTs, $\mathrm{MnO}_{2} /$

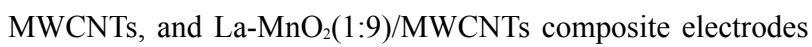
with applied constant current density of $100 \mathrm{~mA} \cdot \mathrm{g}^{-1}$ in a potential range from 0 to $+1 \mathrm{~V}$. The sharp drop in electrode potentials with the acid-treated MWCNTs should be noticed. Whereas, the potential drops became lower when doping $\mathrm{La}$ in the $\mathrm{MnO}_{2} / \mathrm{MWCNTs}$ composite. The specific capacitance was evaluated from the charge-discharge curves, according to the following equation,
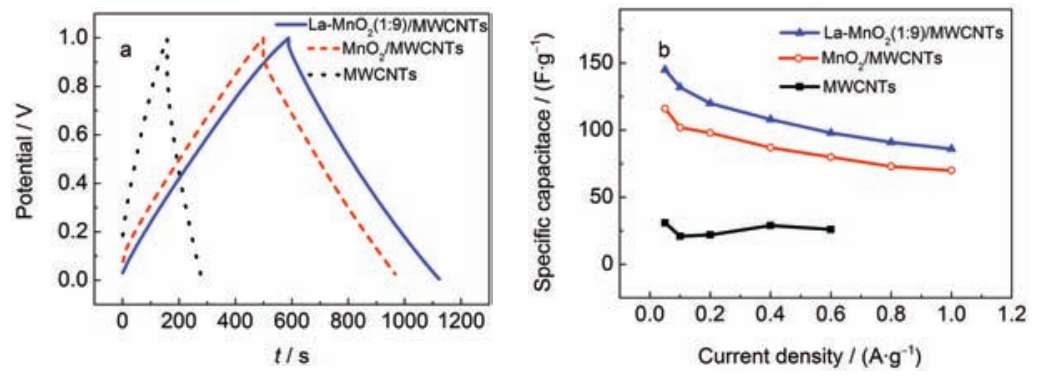

$$
C_{\mathrm{sp}}=\frac{2 I}{m(\mathrm{~d} E / \mathrm{d} t)}
$$

where $I$ is the applied current. $\mathrm{d} E / \mathrm{d} t$ indicates the average slope of these chronopotentiometry curves. $m$ is the mass of each electrode. The specific capacitance of the acid-treated MWCNTs, $\mathrm{MnO}_{2} / \mathrm{MWCNTs}$, and La-MnO 2 (1:9)/MWCNTs composite is ca 31,120 , and $134 \mathrm{~F} \cdot \mathrm{g}^{-1}$, respectively. The symmetry of the charge and discharge characteristics of $\mathrm{La}-\mathrm{MnO}_{2}(1: 9) / \mathrm{MWCNTs}$ composites suggests a good capacitive behavior.

The capacitive performance of the La-doped $\mathrm{MnO}_{2} / \mathrm{MW}$ CNTs composite was investigated by galvanostatic charge/discharge cycling at different current densities. Fig.6b shows the gravimetric discharge capacitance of the acid-treated MWCNTs, $\mathrm{MnO}_{2} / \mathrm{MWCNTs}$, and $\mathrm{La}-\mathrm{MnO}_{2}(1: 9) / \mathrm{MWCNTs}$ materials at current densities from 0.05 to $1.0 \mathrm{~A} \cdot \mathrm{g}^{-1}$ in $0.1 \mathrm{~mol} \cdot \mathrm{L}^{-1} \mathrm{Na}_{2} \mathrm{SO}_{4}$ aqueous solution. It is noteworthy that the capacitance of $\mathrm{La}-$ $\mathrm{MnO}_{2}(1: 9) / \mathrm{MWCNTs}$ is maintained above $86 \mathrm{~F} \cdot \mathrm{g}^{-1}$ even at a high discharge current density of $1.0 \mathrm{~A} \cdot \mathrm{g}^{-1}$. In contrast, the capacitance of the $\mathrm{MnO}_{2} / \mathrm{MWCNTs}$ composite dropped by nearly $60 \%$ at a current density of $1.0 \mathrm{~A} \cdot \mathrm{g}^{-1}$ (Fig.6b).

The charge transfer process in the $\mathrm{La}-\mathrm{MnO}_{2} / \mathrm{MWCNTs}$ electrode was investigated by ac impedance measurements at dc bias of $0 \mathrm{~V}$ with sinusoidal signal of $10 \mathrm{mV}$ over the frequency range from $10 \mathrm{mHz}$ to $40 \mathrm{kHz}$. The Nyquist plots in a three-electrode cell system for the acid-treated MWCNTs,

Fig.6 (a) Galvanostatic charge/discharge of two electrode cells built with acid-treated $\mathrm{MWCNTs} \mathrm{MnO}_{2} / \mathrm{MWCNTs}$, and $\mathrm{La}-\mathrm{MnO}_{2}(1: 9) /$ MWCNTs composites at an applied constant current density of $100 \mathrm{~mA} \cdot \mathrm{g}^{-1}$ in $0.1 \mathrm{~mol} \cdot \mathrm{L}^{-1} \mathrm{Na}_{2} \mathrm{SO}_{4}$ aqueous electrolyte; (b) gravimetric capacitance $v$ discharge current density of acid-treated $\mathrm{MWCNTs}, \mathrm{MnO}_{2} / \mathrm{MWCNTs}$, and $\mathrm{La}-\mathrm{MnO}_{2}(1: 9) / \mathrm{MWCNTs}$ composites; (c) cycling evolution of capacitance of acid-treated $\mathrm{MWCNTs}$, $\mathrm{MnO}_{2} / \mathrm{MWCNTs}$, and $\mathrm{La}-\mathrm{MnO}_{2}(1: 9) / \mathrm{MWCNTs}$ composites, measured at $100 \mathrm{~mA} \cdot \mathrm{g}^{-1}$ discharge current density in $0.1 \mathrm{~mol} \cdot \mathrm{L}^{-1} \mathrm{Na}_{2} \mathrm{SO}_{4}$ aqueous electrolyte 
$\mathrm{MnO}_{2} / \mathrm{MWCNTs}$, and $\mathrm{La}-\mathrm{MnO}_{2}(1: 9) / \mathrm{MWCNTs}$ electrodes are shown in Fig.7. The Nyquist curves can be fitted by a modified Randles circuit ${ }^{22}$ with a set of resistors and capacitors in series and parallel as shown in the inset of Fig.7. $R_{\mathrm{s}}$ element represents the Ohmic resistance of the electrolyte and the internal resistance of the electrode materials. The semicircle in the high-frequency and mid-frequency regions can be fitted by an interfacial charge transfer resistance $R_{\text {Ст }}$ and a double layer capacitance $\mathrm{CPE}_{\mathrm{DL}}$ paralleled to each other. The Warburg element $W_{\mathrm{o}}$ represents the transition part from the high-frequency semicircle to the mid-frequency tail. The straight line parallel to the imaginary axis at very low frequencies is the characteristics of an ideally polarizable capacitance. This capacitance is represented as $C_{\mathrm{L}}$. The EIS spectra were well fitted by the equivalent circuit (Fig.7). The high frequency value of the real part of complex impedance has been used for the estimation of equivalent series resistance (ESR).

Nyquist plot for the $\mathrm{La}-\mathrm{MnO}_{2}(1: 9) / \mathrm{MWCNTs}$ composite in Fig.7 suggests that the $\mathrm{La}_{-} \mathrm{MnO}_{2}$ (1:9)/MWCNTs composite exhibites very low charge transfer resistance. The calculated charge-transfer resistance for the MWCNTs, $\mathrm{MnO}_{2} / \mathrm{MWCNT}$, and $\mathrm{La}-\mathrm{MnO}_{2}(1: 9) / \mathrm{MWCNT}$ electrode is 3.72, 14.21, and 6.93 $\Omega$, respectively. This supports our argument that the presence of La can decrease the resistance of $\mathrm{MnO}_{2} / \mathrm{MWCNTs}$. The lower the charge-transfer resistance, the higher the specific capacitance. Therefore, it is suggested that the doping of $\mathrm{La}$ in the $\mathrm{MnO}_{2} / \mathrm{MWCNTs}$ composite improves the charge transfer process in the electrode, which leads to a higher capacitance. These results are in good agreement with the CV plots in Fig.4.

Long cycling life is a key requirement for the supercapacitor electrodes. The composite electrodes of two electrode cells built with $\mathrm{MnO}_{2} / \mathrm{MWCNTs}$ and $\mathrm{La}-\mathrm{MnO}_{2}(1: 9) / \mathrm{MWCNTs}$ exhibited a decay in specific capacitance, as shown in Fig.6c. On the contrary, MWCNTs had the highest cycling stability. The capacitance of $\mathrm{La}-\mathrm{MnO}_{2}(1: 9) / \mathrm{MWCNTs}$ electrode is more stable

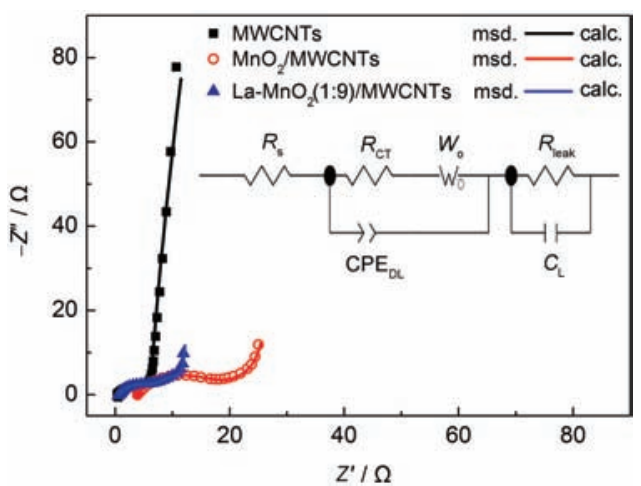

Fig.7 Nyquist plots in a three-electrode cell system of acid-treated MWCNTs, $\mathrm{MnO}_{2} / \mathrm{MWCNTs}$, and $\mathrm{La}-\mathrm{MnO}_{2}(1: 9) /$ MWCNTs composites in $0.1 \mathrm{~mol} \cdot \mathrm{L}^{-1} \mathrm{Na}_{2} \mathrm{SO}_{4}$ aqueous electrolyte $R_{\mathrm{s}}$ : the Ohmic resistance of the electrolyte and the internal resistance of the electrode materials, $R_{\mathrm{CT}}$ : interfacial charge transfer resistance, $\mathrm{CPE}_{\mathrm{DL}}$ : a double layer capacitance. $W_{\mathrm{o}}$ : the Warburg element, $C_{\mathrm{L}}$ : an ideally polarizable capacitance, $R_{\text {leak }}$ : the low-frequency leakage resistance than that of $\mathrm{MnO}_{2} / \mathrm{MWCNTs}$ electrode which suggested the La- $\mathrm{MnO}_{2}(1: 9) / \mathrm{MWCNTs}$ electrode has a long cycling life. The initial decrease in the specific capacitance of electrochemical electrodes is generally observed and is attributed to the poor mechanical stability of the electrode material. However, the fading was obvious for the $\mathrm{MnO}_{2} / \mathrm{MWCNTs}$ composite electrode when it was charged/discharged for more than 1000 cycles. The fading of $\mathrm{MnO}_{2} / \mathrm{MWCNTs}$ is attributed to the formation of $\mathrm{Mn}^{2+}$ and $\mathrm{Mn}^{7+}$ species at $1.0 \mathrm{~V}^{23}$ It can be inferred that the stability of $\mathrm{MnO}_{2} / \mathrm{MWCNTs}$ is improved by doping $\mathrm{La}^{3+}$ in such neutral electrolyte. Therefore significant improvement in cycling stability was achieved for the La-doped $\mathrm{MnO}_{2} / \mathrm{MWCNTs}$ composites. Our results suggest that doping with $\mathrm{La}$ is a prospective method to overcome the intrinsic low conductivity of $\mathrm{MnO}_{2}$ and increase the specific capacitance and cycling performance of composite electrodes.

It should be pointed out that the performances of manganese oxide were studied in three-electrode systems in positive potential range in most literature, ${ }^{14,24-26}$ while only few reports available on the performance of symmetric two-electrode capacitors evaluated by chronopotentiometry where two manganese oxide electrodes worked in different potential ranges. ${ }^{27,28}$

Since the pseudocapacitance of manganese oxides in aqueous medium is attributed to reversible redox transitions involving protons and/or cations exchange with the electrolyte following the equation: ${ }^{29}$

$\mathrm{MnO}_{a}(\mathrm{OH})_{b}+\delta \mathrm{H}^{+}+\delta \mathrm{e}^{-} \rightleftharpoons \mathrm{MnO}_{a-\delta}(\mathrm{OH})_{b+\delta}$ where $\mathrm{MnO}_{a}(\mathrm{OH})_{b}$ and $\mathrm{MnO}_{a-\delta}(\mathrm{OH})_{b+\delta}$ indicate interfacial oxymanganese species at the higher and lower oxidation states, respectively. To avoid the partial dissolution of the electrode, the solubility of either Mn(II) or Mn(VII) in the electrolytic solution should be avoided during charging and discharging the capacitor. From the Pourbaix potential-pH diagram for manganese ${ }^{30}$ it is possible to determine that the reactions of $\mathrm{Mn}(\mathrm{IV})$ to $\mathrm{Mn}(\mathrm{II})$ and $\mathrm{Mn}(\mathrm{IV})$ into $\mathrm{Mn}$ (VII) occur at potentials of 0.5 and $1.4 \mathrm{~V}(v s \mathrm{NHE})$ for $\mathrm{pH} 5.4$, respectively.

As the cyclability of the $\mathrm{MnO}_{2} / \mathrm{MWCNTs}$ electrode was fairly steady in the three-electrode system, ${ }^{14}$ we presumed that the reason for the poor cyclability of the same electrode in the two-electrode as shown in Fig.6c could be due to the dissolution of negative electrode. Therefore, we have measured the potential of both electrodes when the cell voltage varied between 0 and $1.0 \mathrm{~V}$ during the galvanostatic charge-discharge cycling in $0.1 \mathrm{~mol} \cdot \mathrm{L}^{-1} \mathrm{Na}_{2} \mathrm{SO}_{4}$ with a $\mathrm{pH}$ of 5.4 . For this purpose, we used a three-electrode cell consisting of two $\mathrm{MnO}_{2} / \mathrm{MWCNTs}$ composite electrodes, one as the working electrode and the other as the auxiliary one, and a $\mathrm{Hg} / \mathrm{Hg}_{2} \mathrm{SO}_{4}$ reference electrode. Fig. 8 presents the variation of the cell voltage during chargedischarge cycling and the potential profile for both positive and negative electrodes. It shows that for the $\mathrm{MnO}_{2} / \mathrm{MWCNTs}$ in $0.1 \mathrm{~mol} \cdot \mathrm{L}^{-1} \mathrm{Na}_{2} \mathrm{SO}_{4}$ with a $\mathrm{pH}$ of 5.4 , the initial potential for both electrodes in the discharged state of the capacitor is 0.08 $\mathrm{V}$ (vs NHE). After charging the capacitor to $1.0 \mathrm{~V}$, the potential 


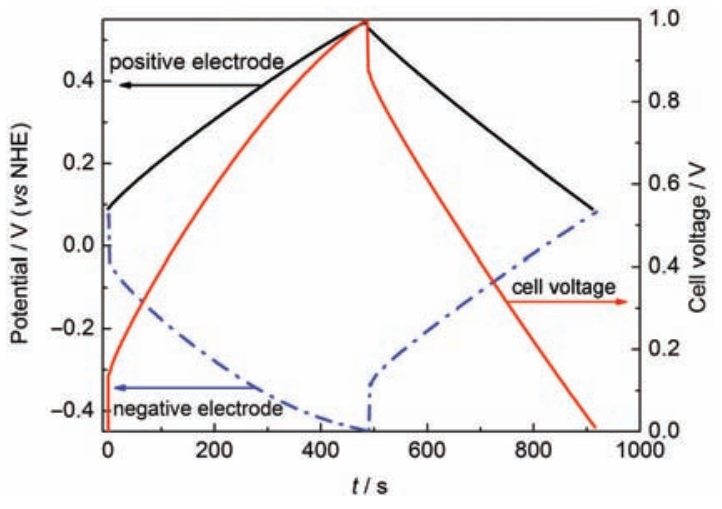

Fig.8 Galbnanostatic charge/discharge cycle $\left(I=100 \mathrm{~mA} \cdot \mathrm{g}^{-1}\right)$ for the capacitor and for the positive and negative electrodes in a three-electrode cell

The working and auxiliary electrodes of the three-electrode cell are made from the $\mathrm{MnO}_{2} / \mathrm{MWCNTs}$. The results are presented $v s \mathrm{NHE}$ in $0.1 \mathrm{~mol} \cdot \mathrm{L}^{-1} \mathrm{Na}_{2} \mathrm{SO}_{4}$ with a $\mathrm{pH}$ of 5.4 .

of the positive electrode increases up to $0.54 \mathrm{~V}$, while for the negative one it decreases from 0.08 to $-0.45 \mathrm{~V}$ ( $v s$ NHE). Since the irreversible reduction of $\mathrm{Mn}$ (IV) into $\mathrm{Mn}(\mathrm{II})$ starts to occur at $0.5 \mathrm{~V}$ in a solution with a $\mathrm{pH}$ of $5.4,{ }^{30}$ it demonstrates that the negative electrode is actually working below this potential, which results in a partial dissolution of the active material in the electrolyte. Hence, the capacitance decrease observed in Fig.6c during the repeated cycling of the capacitor in $0.1 \mathrm{~mol} \cdot \mathrm{L}^{-1} \mathrm{Na}_{2} \mathrm{SO}_{4}$ aqueous solution is due to the deterioration of the negative electrode.

\section{Conclusions}

La-doping in the $\mathrm{MnO}_{2} / \mathrm{MWCNTs}$ composite resulted in performance improvement with respect to discharge capacitance and cycling stability. The highest working current density for La- $\mathrm{MnO}_{2}(1: 9) / \mathrm{MWCNTs}$ is above $1.0 \mathrm{~A} \cdot \mathrm{g}^{-1}$, which is higher than that of MWCNTs. The electrochemical performance of the composite electrode was affected by the La:Mn atomic ratio. The electrochemical properties of the composite with a La: $\mathrm{Mn}$ atomic ratio of $1: 9$ reached $130 \mathrm{~F} \cdot \mathrm{g}^{-1}$, which was higher than other composites. La-doped $\mathrm{MnO}_{2} / \mathrm{MWCNTs}$ is a prospective candidate electrode material for electrochemical supercapacitors.

\section{References}

(1) Conway, B. E. Electrochemical Supercapacitors: Scientific Fundamentals and Technological Applications; Kluwer Academic/Plenum Publishers: New York, 1999.

(2) Burke, A. Electrochim. Acta 2007, 53, 1083.

(3) Conway, B. E.; Pell, W. G. J. Solid State Electrochem. 2003, 7, 637.

(4) Qu, D. Y.; Shi, H. J. Power Sources 1998, 74, 99.

(5) Arabale, G.; Wagh, D.; Kulkarni, M.; Mulla, I. S.; Vernekar, S. P.; Vijayamohanan, K.; Rao, A. M. Chem. Phys. Lett. 2003, 376,
207.

(6) Sharma, R. K.; Karakoti, A.; Seal, S.; Zhai, L. J. Power Sources 2010, 195, 1256.

(7) Zein, S. H. S.; Yeoh, L. C.; Chai, S. P.; Mohamed, A. R.; Mahayuddin, M. E. M. J Mater. Process Technol. 2007, 190, 402.

(8) Toupin, M.; Brousse, T.; Bélanger, D. Chem. Mater. 2004, 16, 3184.

(9) Subramanian, V.; Zhu, H. W.; Wei, B. Q. Electrochem. Commun. 2006, 8, 827.

(10) Shao, G. J.; Yao, Y.; Zhang, S. P.; He, P. Rare Metals 2009, 28, 132.

(11) Mančić, D.; Paunović, V.; Vijatović, M.; Stojanović, B.; Živković, L. Science of Sintering 2008, 40, 283.

(12) Ma, S. B.; Ahn, K. Y.; Lee, E. S.; Oh, K. H.; Kim, K. B. Carbon 2007, 45, 375.

(13) Athouël, L.; Moser, F.; Dugas, R.; Crosnier, O.; Bélanger, D.; Brousse, T. J. Phys. Chem. C 2008, 112, 7270.

(14) Jin, X.; Zhou, W.; Zhang, S.; Chen, G. Z. Small 2007, 3, 1513.

(15) Kovtyukhova, N. I.; Mallouk, T. E.; Pan, L.; Dickey, E. C. J. Am. Chem. Soc. 2003, 125, 9761.

(16) Holzinger, M.; Vostrowsky, O.; Hirsch, A.; Hennrich, F.; Kappes, M.; Weiss, R.; Jellen, F. Angew. Chem. Int. Edit. 2001, 40, 4002 .

(17) Kim, U. J.; Furtado, C. A.; Liu, X. M.; Chen, G. G.; Eklund, P. C. J. Am. Chem. Soc. 2005, 127, 15437.

(18) Kuznetsova, A.; Mawhinney, D. B.; Naumenko, V.; Yates, J. T.; Liu, J.; Smalley, R. E. Chem. Phys. Lett. 2000, 321, 292.

(19) Lu, K. L.; Lago, R. M.; Chen, Y. K.; Green, M. L. H.; Harris, P. J. F.; Tsang, S. C. Carbon 1996, 34, 814.

(20) Xie, X. F.; Gao, L. Carbon 2007, 45, 2365.

(21) White, A. M.; Slade, R. C. T. Electrochim. Acta 2004, 49, 861.

(22) Masarapu, C.; Zeng, H. F.; Hung, K. H.; Wei, B. Q. ACS Nano 2009, 3, 2199.

(23) Hu, C. C.; Wang, C. C. J. Electrochem. Soc. 2003, 150, A1079.

(24) Wu, M. S.; Chiang, P. C. J. Electrochemical and Solid State Letters 2004, 7, A123.

(25) Yan, J.; Fan, Z. J.; Wei, T.; Cheng, J.; Shao, B.; Wang, K.; Song, L. P.; Zhang, M. L. J. Power Sources 2009, 194, 1202.

(26) Li, Y.; Xie, H. Q.; Wang, J. F.; Chen, L. F. Mater. Lett 2011, 65, 403.

(27) Raymundo-Piñero, E.; Khomenko, V.; Frackowiak, E.; Béguin, F. J. Electrochem. Soc. 2005, 152, A229.

(28) Fang, D. L.; Wu, B. C.; Mao, A. Q.; Yan, Y.; Zheng, C. H. J. Alloy. Compd. 2010, 507, 526.

(29) Wu, M.; Snook, G. A.; Chen, G. Z.; Fray, D. J. Electrochem. Commun. 2004, 6, 499.

(30) Pourbaix, M. Atlas of Electrochemical Equilibria in Aqueous Solutions; National Association of Corrosion Engineers: Honston, 1974. 